\title{
Pertumbuhan Generasi Pertama (G1) Hasil Silangan Merawangarab Umur 1-12 Minggu
}

\author{
Performance of G1 Merawang-Arab Crossing Growth at 1-12 Weeks Age
}

\author{
S. Darwati ${ }^{1}$, H. Nurcahya ${ }^{2}$, R. Afnan ${ }^{1}$, V. S. Maulana ${ }^{1}$, \& P. Rohamtullah ${ }^{1}$ \\ ${ }^{1}$ Departemen Ilmu Produksi dan Teknologi Peternakan IPB \\ ${ }^{2}$ Program Studi Biologi, Universitas Nasional \\ Email koresponden author: darwatisri63@gmail.com
}

\begin{abstract}
Merawang and arab are 2 Indonesia local chicken that have potensial to be developed. Crossing of merawang and arab chicken aims to improve genetic quality of local chickens. G1 MA as results interse of MA is expected to be developed as local chicken producing eggs. To produce superior laying hens, growth of ages 1 to 12 weeks is very important because starter ang grower phasethis is the critical phase to produce superior laying hens. This study aimed to examine the growth of G1 MA as a result of MA interse crosses compared to MA (Go) aged 1-12 weeks. The number of DOC of G1 MA chicken is 98 birds and DOC of Go MA chicken $1 \mathrm{~s} 147$ birds. The $100 \%$ commercial feed for broiler starter phase until the age of 3 weeks and age $>3$ weeks began to be mixed with rice bran gradually so that the age $>$ 5-12 weeks was given a mixture of $60 \%$ commercial feed and $40 \%$ rice bran. The variables measured were body weight, consumption, feed conversion, and mortality. The data obtained were $t$ test. The results of the weight of the DOC G1. The results of the weight of the DOC G1 MA were significantly heavier than the MA, but with no different growth rates, the average age of 12 weeks G1 MA and MA in the same sex were not different, G1 MA and Go MA male chicken were 1099 and $1087 \mathrm{~g}$ respectivelly, while females were 976 and $970 \mathrm{~g}$, feed consumption ranging 3759 - $3812 \mathrm{~g}$, and feed conversion ranging from 3.67 to 4.11. The conclusion that G1 MA and Go MA had composition genetic $50 \%$ merawang chicken and $50 \%$ arab chicken had same growth performance.
\end{abstract}

Keywords: first generation (G1), growth, merawangarab (MA)

\section{PENDAHULUAN}

Keragaman ayam lokal yang ada di Indonesia merupakan sumber genetik yang perlu dikaji dan dikembangkan untuk meningkatkan peran ayam lokal sebagai penyedia protein hewani asal unggas. Hal ini mengingat hingga saat ini kebutuhan telur dan daging unggas dipenuhi oleh ayam ras petelur dan pedaging.

Kendala pengembangan ayam lokal adalah produktivitas rendah, pertumbuhan lambat, produksi telur rendah, dan sifat mengeram yang tinggi. Selain itu pemeliharaan ayam lokal di Indonesia hanya sebagai sambilan sehingga pemeliharaan serta pemberian pakan masih tradisional, hal ini menyebabkan perkembangan populasi maupun produktivitas ayam lokal belum maksimal seperti dikemukakan Sugama dan Suyasa (2014).

Upaya memanfaatkan 2 rumpun ayam lokal merawang dan arab untuk disilangkan untuk mendapatkan ayam silangan merawangarab sehingga dapat diwujudkan harapan peningkatan produktivitas ayam lokal. Ayam merawang disebut juga ayam bangka. Penamaan tersebut didasarkan pada penyebaran dari ayam yang terkonsentrasi di Kecamatan Merawang di daerah Sumatera bagian selatan khususnya di Pulau Bangka (Diwyanto dan Prijono 2007). Ayam merawang sangat potensial untuk dikembangkan sebagai ayam penghasil telur dan lebih tinggi dibandingkan ayam kampung. Abubakar et al. (2005) menyatakan produksi telur ayam merawang rata-rata 165 butir ekor 1 tahun $^{-1}$, sedangkan ayam kampung hanya 40-60 butir ekor $^{1}$ tahun $^{-1}$. Adapun ayam produksi telur ayam arab dapat mencapai 190-250 butir ekor-1 tahun-1 dengan bobot telur 30-35 g dan hampir tidak memiliki sifat mengeram sehingga waktu bertelur menjadi lebih panjang (Natalia et al. 2005). Ayam arab juga salah satu ayam lokal yang memiliki daya adaptasi yang baik terhadap iklim tropis di Indonesia. Hal ini sesuai dengan pernyataan Yusdja et al. (2005) ayam arab memiliki daya tahan tubuh yang baik terhadap penyakit dan perubahan cuaca di Indonesia.

Persilangan antara ayam merawang dengan ayam arab (MA) dan generasi pertama (G1) hasil interse MA diharapkan dapat dikebangkan sebagai ayam lokal penghasil telur yang meningkatkan mutu genetik ayam 
lokal. Untuk menghasilkan ayam petelur yang unggul, pertumbuhan umur 1 sampai 12 minggu sangat penting. Hal ini disebabkan karena fase kritis untuk menghasilkan ayam lokal petelur yang unggul yaitu pada fase starter dan grower. Fase starter ayam kampung yaitu umur 1 hari -8 minggu, dan fase grower umur 8 minggu - 12 minggu (Zainudin et al. 2000). Olehkarenanya penelitian ini berujuan mengkaji pertumbuhan hasil persilangan ayam merawang $\times$ arab (MA) dan Generasi pertama (G1) hasil interse MA umur 1-12 minggu.

\section{MATERI DAN METODE}

\section{Waktu dan Tempat Penelitian}

Penelitian dilaksanakan di Laboratorium Lapang Divisi Pemuliaan dan Genetika Ternak Fakultas Peternakan, Institut Pertanian Bogor. Penelitian dilakukan pada bulan November 2017 sampai Februari 2018.

\section{Materi dan Alat}

Materi yang digunakan pada penelitian adalah indukan ayam merawang (M) dan ayam arab (A) untuk memperoleh DOC (Day Old Chick). DOC merawangarab (MA) sebanyak 147 ekor. Selanjutnya persilangan interse MA untuk menghasilkan G1 MA dengan DOC berjumlah 98 ekor yang dihasilkan menjadi materi yang diamati pertumbuhannya pada penelitian ini.

Untuk menghasilkan ayam MA digunakan 3 ekor jantan merawang dan 9 ekor betina arab. Selanjutnya untuk menghasilkan G1 MA digunakan 2 ekor ayam jantan MA dan 6 ekor ayam betina MA. Pakan yang digunakan pakan komersial untuk ayam pedaging fase starter. Dedak padi dicampurkan untuk pakan anak ayam setelah berumur 3 minggu secara bertahap. Untuk tetua diberi pakan komersial petelur $60 \%$ dicampur $40 \%$ dedak padi.

Alat yang digunakan kandang berukuran 1,5 m $\times 1,5 \mathrm{~m}$ sebanyak 12 unit, tempat minum, tempat pakan, mesin tetas, egg tray, brooder, dan timbangan. Kandang dialasi litter sekam.

\section{Prosedur}

\section{Persilangan}

Persilangan ayam tetua sebanyak 3 unit kandang. Setiap diisi 1 jantan dengan 3 betina (ratio 1:3) baik saat untuk menghasilkan MA dan 1 jantan dengan 2 betina untuk menghasilkan G1 MA. Ilustrasi persilangan ayam disajikan pada Gambar 1.

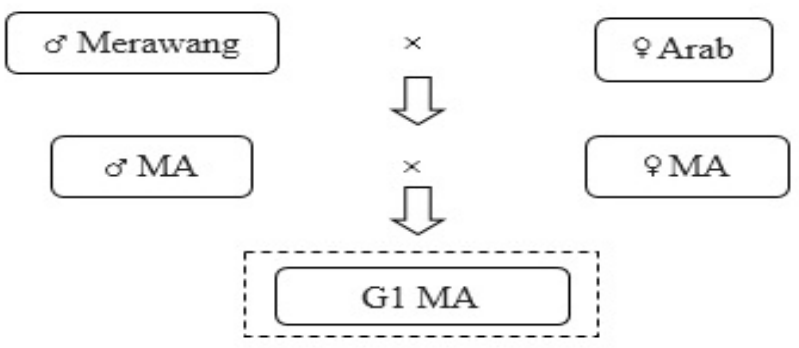

Gambar 1. Skema persilangan untuk mendapatkan G1 MA

\section{Pemeliharaan}

Pemeliharaan ayam hasil persilangan dilakukan di kandang koloni. Ayam dipelihara Secara teoritis hasil persilangan antara MA $\times$ MA akan menghasilkan, MM (25\% tipe induk merawang), $0 \%$ MB campuran merawang arab dan 25\% tipe arab) secara teoritis akan ada tiga tipe ayam di G1 nya). Vaksinasi ND untuk pencegahan terhadap penyakit ND dilakukan pada umur 3 hari dan 3 minggu melalui tetes mata, kemudian pada umur 3 bulan disuntik intramuskular. Pemberian vitamin dilakukan saat menetas (DOC) sampai ayam berumur 2 minggu. Selanjutnya pemberian vitamin dilakukan eksidental yaitu pada saat sebelum dan sesudah penimbangan.

\section{Pemberian Pakan dan Air Minum}

Pemberian pakan diberikan 2 kali sehari yaitu pagi dan sore. Air minum diberikan ad libitum selama pemeliharaan. Pakan yang digunakan yaitu pakan komersil yaitu pakan untuk ayam pedaging fase starter dan dedak padi. Pakan komersial untuk ayam pedaging fase starter berbentuk crumble diberikan pada anak ayam umur sehari (DOC) sampai umur 3 minggu.

Mulai umur $>3$ minggu anak ayam diberi campuran pakan komersial dengan dedak padi. Ayam berumur $>3-4$ minggu diberi pakan campuran $80 \%$ pakan komersial dengan $20 \%$ dedak padi. Ayam umur $>4-5$ minggu diberi pakan campuran $70 \%$ pakan komersial dengan $30 \%$ dedak padi. Ayam umur $>5-12$ minggu diberi pakan campuran $60 \%$ pakan komersial dengan $40 \%$ dedak padi. Kandungan nutrisi pakan yang digunakan dapat dilihat pada Tabel 1 .

\section{Analisis Data}

Analisis data deskriptif digunakan untuk membandingkan pertumbuhan antara ayam G1 MA jantan dengan ayam MA jantan, dan ayam G1 MA betina dengan ayam MA betina. Pengukuran dilakukan setiap 1 minggu selama 12 minggu. Uji t menurut Mattjik dan Sumertajaya (2006) digunakan untuk membandingkan nilai tengah peubah yang diukur antara ayam G1 MA dengan ayam

Tabel 1. Kandungan nutrisi pakan untuk masa pertumbuhan

\begin{tabular}{lccccc}
\hline Nutrisi & $(100 \mathrm{D})$ & $(100 \mathrm{~K})$ & $\begin{array}{r}(80 \mathrm{~K}: \\
20 \mathrm{D})\end{array}$ & $\begin{array}{r}(70 \mathrm{~K}: \\
\text { 30D })\end{array}$ & $\begin{array}{r}(60 \mathrm{~K}: \\
40 \mathrm{D})\end{array}$ \\
\hline $\begin{array}{l}\text { Bahan } \\
\text { kering (\%) }\end{array}$ & 88,14 & 89,60 & 89,30 & 89,65 & 89,48 \\
Abu (\%) & 10,98 & 6,46 & 731 & 7,71 & 8,08 \\
$\begin{array}{l}\text { Protein } \\
\text { kasar (\%) }\end{array}$ & 11,53 & 19,21 & 19,01 & 16,19 & 15,52 \\
$\begin{array}{l}\text { Serat } \\
\text { kasar (\%) }\end{array}$ & 8,81 & 2,52 & 2,76 & 3,41 & 3,02 \\
$\begin{array}{l}\text { Lemak } \\
\text { kasar (\%) }\end{array}$ & 10,37 & 8,68 & 7,85 & 8,14 & 9,29 \\
\hline
\end{tabular}

Keterangan: K:Pakan komersil, D:Dedak padi, 100 D dan $100 \mathrm{~K}$ berdasarkan hasil analisis Laboratorium Pusat Penelitian Sumberdaya Hayati dan Bioteknologi IPB (2018) 


\section{HASIL DAN PEMBAHASAN}

\section{Bobot Badan}

Pada masa pertumbuhan ayam, bobot badan meningkat seiring bertambahnya umur. Bobot badan sebagai indikator produktivitas ayam silangan merawang ara pada penelitian ini badan merupakan sifat yang memiliki nilai ekonomis. Berdasarkan penelitian ini bobot badan G1 MA dan MA sebagai tetuanya pada umur 1-12 minggu disajikan pada Tabel 2.

Secara statistik bobot badan ayam G1 MA pada saat DOC sangat berbeda $(\mathrm{P}<0,01)$ dengan tetuanya MA. Bobot DOC G1 yaitu $30,31 \pm 2,88 \mathrm{~g}$ dan MA yaitu 27,37 $\pm 3,26 \mathrm{~g}$. Hal ini disebabkan adanya peningkatan bobot telur tetas ayam MAxMA atau interse MA. Bobot telur tetas MA $\times$ MA lebih besar yaitu 46,55 $\pm 3,71 \mathrm{~g}$ dibandingkan dengan bobot telur tetas induk ayam arab pada persilangan $\mathrm{M} \times \mathrm{A}$ 43,42 $\pm 4,29 \mathrm{~g}$. Hal ini sesuai disampaikan Rajab (2013) dan Butcher et al. (2004) bahwa bobot telur memiliki hubungan sangat nyata dengan bobot tetas. Semakin besar bobot telur akan dihasilkan bobot tetas DOC yang besar pula, hal ini karena ada hubungan sangat nyata antara bobot telur tetas dengan bobot tetas $(P<0,01)$. Semakin tinggi bobot telur yang ditetaskan akan dihasilkan bobot tetas yang lebih berat. Wineland (2000) melaporkan bobot telur dapat digunakan sebagai indikator bobot tetas. Selanjutnya hasil penelitian Hermawan (2000) bahwa ada hubungan yang sangat nyata antara bobot telur tetas dengan bobot tetas pada ayam kampung.
Bobot badan G1 MA dan MA tetuanya pada umur 12 minggu lebih berat dari ayam merawang umur 12 minggu hasil penelitian Sesmira (2002) bahwa bobot merawang jantan $919,1 \mathrm{~g}$ dan merawang betina 719,9 g. Demikian halnya dibandingkan dengan ayam arab pada penelitian Natamijaya et al. (2003) bahwa ayam arab jantan pada umur 12 minggu 705,2 g dan ayam arab betina 586,3 g. Peningkatan bobot badan G1 MA dan MA tetua dari tetua merawang dan arab menunjukan adanya pengaruh heterosis akibat persilangan antar 2 rumpun ayam. Hal ini merujuk Noor (2010) bahwa efek heterosis dapat terjadi apabila rataan performa ternak hasil persilangan lebih besar dibandingkan dengan tetuanya.

Pada penelitian ini walaupun bobot DOC berbeda namun bobot umur 12 minggu antara G1 MA dan tetuanya MA baik pada jantan maupun betina tidak berbeda. Hal ini menunjukkan pula bahwa peningkatan bobot badan selama 12 minggu pemeliharaan tidak berbeda nyata pada jenis kelamin yang sama antara G1 MA dengan MA tetuanya sehingga bobot badan G1 MA mendekati sama dengan MA. Komposisi genetik $50 \%$ merawang dan $50 \%$ arab pada G1 MA seperti halnya tetuanya MA menunjukan pertumbuhan yang sama pada penelitian ini.

\section{Konsumsi Pakan}

Konsumsi pakan persilangan interse ayam MA dan AM (G1 MA) dan MA tetuanya sebagai pembanding pada penelitian ini disajikan pada Tabel 3. Konsumsi ayam G1 MA umur 1-4 minggu sebesar 481,5 g dan ayam MA

Tabel 2. Bobot badan G1 MA dan MA tetuanya pada umur 1-12 minggu

\begin{tabular}{lcc}
\hline \multirow{2}{*}{ Minggu } & \multicolumn{2}{c}{$\overline{\mathrm{x}} \pm \mathrm{sb}(\mathrm{KK} \%)$ Bobot Badan } \\
\cline { 2 - 3 } & & \multicolumn{2}{c}{$\left.\mathrm{MA}^{*}\right)$} \\
\hline & & $\mathrm{g}$ ekor-1 \\
DOC & $30,31 \pm 2,88(9,51) \mathrm{A}$ & $27,37 \pm 3,26(11,92) \mathrm{B}$ \\
1 & $49,84 \pm 7,50(15,05) \mathrm{A}$ & $44,57 \pm 8,54(19,15) \mathrm{B}$ \\
2 & $103,97 \pm 28,57(27,48) \mathrm{A}$ & $87,11 \pm 26,98(30,97) \mathrm{B}$ \\
3 & $162,62 \pm 32,29(19,87) \mathrm{A}$ & $139,98 \pm 34,62(22,73) \mathrm{B}$ \\
4 & $238,55 \pm 43,44(18,21) \mathrm{B}$ & $196,65 \pm 41,48(19,18) \mathrm{B}$ \\
\hline
\end{tabular}

$\overline{\mathrm{x}} \pm \mathrm{sb}(\mathrm{KK} \%)$ Bobot Badan

\begin{tabular}{|c|c|c|c|c|}
\hline \multirow[t]{2}{*}{ Minggu } & \multicolumn{2}{|c|}{ Jantan } & \multicolumn{2}{|c|}{ Betina } \\
\hline & G1 MA & MA & G1 MA & MA \\
\hline 5 & $335,1 \pm 49,5(14,76)$ & $306,2 \pm 47,3(15,44)$ & $295,5 \pm 44,5(15,05)$ & $284,1 \pm 54,8(19,29)$ \\
\hline 6 & $424,3 \pm 58,3(13,75)$ & $406,6 \pm 52,0(12,78)$ & $379,6 \pm 44,2(11,64)$ & $371,3 \pm 64,4(17,35)$ \\
\hline 7 & $522,8 \pm 78,6(15,04)$ & $500,3 \pm 63,3(12,65)$ & $475,65 \pm 53,19(33 ; 11,18)$ & $460,5 \pm 69,9(15,18)$ \\
\hline 8 & $629,3 \pm 99,6(15,83)$ & $614,7 \pm 74,8(12,16)$ & $575,39 \pm 47,24(8,21)$ & $560,3 \pm 82,8(14,77)$ \\
\hline 9 & $729,90 \pm 110,3(15,11)$ & $733,5 \pm 73,0(9,95)$ & $676,48 \pm 49,74(33 ; 7,35)$ & $662,1 \pm 92,5(1,97)$ \\
\hline 10 & $843,10 \pm 121,6(14,42)$ & $846,5 \pm 69,3(8,19)$ & $763,5 \pm 69,5(9,11)$ & $748,5 \pm 102,3(13,67)$ \\
\hline 11 & $976,1 \pm 121,7(12,47)$ & $967,1 \pm 121,7(12,47)$ & $871,0 \pm 63,4(6,55)$ & $867,4 \pm 88,5(10,25)$ \\
\hline 12 & $1099 \pm 121,4(11,04)$ & $1087 \pm 60,0(5,52)$ & $976,5 \pm 63,5(6,5)$ & $970,2 \pm 80,4(8,28)$ \\
\hline PBB & $1063,98 \pm 50,7(13,3)$ & $1059 \pm 59,3(7,22)$ & $950 \pm 17,2 \quad(10,8)$ & $942.6 \pm 80,6 \quad(8,55)$ \\
\hline $12 \mathrm{Mgg}$ & & & & \\
\hline
\end{tabular}

*) Penelitian Darwati et al. (2017), $\mathrm{A}=\mathrm{Arab}, \mathrm{M}=$ Merawang, $\mathrm{MA}=$ Merwang Arab, $\mathrm{AM}=\mathrm{Arab}$ Merawang $\overline{\mathrm{x}}=\operatorname{rataan}, \mathrm{sb}=\operatorname{simpangan}$ baku, $\mathrm{KK}=$ Koefisien keragaman, $\mathrm{DOC}=$ Day Old Chick, Angka disertai huruf besar berbeda pada baris yang sama menunjukan berbeda nyata $(\mathrm{P}<0,05)$, 
Darwati et al.

Jurnal Ilmu Produksi dan Teknologi Hasil Peternakan 6 (2): 67-72

Tabel 3. Konsumsi persilangan interse ayam G1 MA dan MA pada umur 1-12 minggu

\begin{tabular}{|c|c|c|c|c|}
\hline \multirow[t]{2}{*}{ Minggu } & \multicolumn{4}{|c|}{$\overline{\mathrm{x}} \pm \mathrm{sb}(\mathrm{KK} \%)$ Konsumsi } \\
\hline & \multicolumn{2}{|c|}{ G1 MA } & \multicolumn{2}{|c|}{ MA* } \\
\hline & \multicolumn{4}{|c|}{ g ekor-1 } \\
\hline 1 & \multicolumn{2}{|c|}{$46,91 \pm 0,94(2,01)$} & \multicolumn{2}{|c|}{$45,86 \pm 0,52(1,14)$} \\
\hline 2 & \multicolumn{2}{|c|}{$96,74 \pm 0,94(0,98)$} & \multicolumn{2}{|c|}{$95,09 \pm 0,78(0,82)$} \\
\hline 3 & \multicolumn{2}{|c|}{$144,66 \pm 1,92(1,93)$} & \multicolumn{2}{|c|}{$144,54 \pm 0,97(0,67)$} \\
\hline 4 & \multicolumn{2}{|c|}{$193,20 \pm 1,03(0,53)$} & \multicolumn{2}{|c|}{$190,56 \pm 1,00(0,53)$} \\
\hline$\sum(1-4)$ & \multicolumn{2}{|c|}{481,517} & \multicolumn{2}{|c|}{468,203} \\
\hline \multirow[t]{3}{*}{ Minggu } & \multicolumn{2}{|c|}{ Jantan } & \multicolumn{2}{|c|}{ Betina } \\
\hline & G1 MA & MA & G1 MA & MA \\
\hline & \multicolumn{4}{|c|}{ g ekor-1 } \\
\hline 5 & $257,8 \pm 44(17,07)$ & $234,69 \pm 6,84(2,92)$ & $237,13 \pm 3,10(1,31)$ & $232,66 \pm 8,92(3,83)$ \\
\hline 6 & $291,02 \pm 1,32(0,45)$ & $286,80 \pm 4,78(1,67)$ & $288,93 \pm 2,53(0,87)$ & $285,54 \pm 5,76(2,02)$ \\
\hline 7 & $340,97 \pm 1,85(0,54)$ & $336,37 \pm 3,39(1,01)$ & $335,15 \pm 10,66(3,18)$ & $335,73 \pm 4,21(1,25)$ \\
\hline 8 & $389,71 \pm 2,03(0,52)$ & $385,15 \pm 4,11(1,07)$ & $376,16 \pm 19,66(5,23)$ & $384,62 \pm 4,64(1,21)$ \\
\hline 9 & $438,89 \pm 1,49(0,34)$ & $435,00 \pm 3,21(0,74)$ & $431,16 \pm 3,15(0,73)$ & $430,23 \pm 2,44(0,57)$ \\
\hline 10 & $487,36 \pm 2,24(0,46)$ & $484,07 \pm 3,23(0,67)$ & $483,32 \pm 5,58(5,58)$ & $480,00 \pm 0,92(0,19)$ \\
\hline 11 & $537,86 \pm 2,22(0,41)$ & $535,43 \pm 2,39(0,45)$ & $531,38 \pm 6,44(1,21)$ & $530,10 \pm 1,59(0,30)$ \\
\hline 12 & $587,65 \pm 0,43(0,07)$ & $586,35 \pm 1,76(0,30)$ & $580,62 \pm 7,68(1,32)$ & $580,87 \pm 2,76(0,47)$ \\
\hline$\sum(5-12)$ & 3331,26 & 3283,86 & 3263,8 & 3259,75 \\
\hline
\end{tabular}

*) Penelitian Darwati et al. (2017), MA = Merawang arab, AM = Arab merawang, $\overline{\mathrm{x}}=$ rataan, $\mathrm{sb}=$ simpangan baku, $\mathrm{KK}=\mathrm{Koefisien}$ keragaman, Angka disertai huruf kecil berbeda pada baris yang sama menunjukan berbeda nyata $(\mathrm{P}<0,05)$.

memiliki konsumsi yang lebih rendah yaitu $468,2 \mathrm{~g}$ lebih rendah dari MA tetuanya. Hasil penelitian Darwati et al. (2017) bahwa jumlah konsumsi ayam MA pada umur 1-4 minggu yaitu 476,0 g. Hasil penelitian ini menunjukan bahwa terdapat peningkatan penggunaan pakan untuk pemeliharaan selama 4 minggu pertama untuk ayam G1 MA dibanding tetuanya. Hal ini sesuai dengan pertumbuhan G1 MA yang berat DOCnya lebih besar dibandingkan MA tetuanya membutuhkan asupan nutrisi lebih banyak dari MA. Hal ini mendukung pernyataan Amrullah (2004) semakin besar ayam semakin banyak pakan yang dibutuhkan untuk hidup pokok sehingga menyebabkan konsumsi pakan meningkat selama masa produksi.

Konsumsi pakan ayam persilangan G1 MA dan MA pada umur 5 minggu setelah dipisahkan jantan dan betina, maka hasil uji statistik konsumsi pakan ayam G1 MA dan MA jenis kelamin jantan atau betina pada umur 5-12 minggu tidak berbeda nyata ( $P>0,05)$, dengan demikian konsumsi pakan selama 12 minggu pemeliharaan sama.

\section{Konversi Pakan}

Rataan konversi pakan G1 MA umur 1-4 minggu yaitu 2,615 $\pm 0,288$ dan rataan konversi pakan ayam MA pada umur yang sama $1,851 \pm 0,204$. Konversi pakan umur 1-4 minggu ayam G1 MA lebih tinggi dibandingkan tetuanya MA. Konversi pakan G1 MA dan MA pada umur 1-4 minggu disajikan pada Tabel 4.

Konversi pakan G1 MA pada minggu ke-1 lebih tinggi dari tetuanya MA. Namun seiring bertambah umur konversi pakan antara G1 MA dengan MA tetuanya tidak berbeda.

Berdasarkan hasil uji statistik, rataan nilai konversi pakan ayam jantan G1 MA dan MA tidak berbeda nyata $(\mathrm{P}>0,05)$. Tingginya nilai konversi pakan dapat disebabkan karena tingkah laku ayam yang lebih suka mengais dan memilih pakan. Curtis (1983) mengatakan bahwa pakan yang tumpah dan bercampur dengan litter sehingga pakan terbuang dan perhitungan pakan lebih besar daripada pakan yang dikonsumsi.

\section{Mortalitas}

Mortalitas ayam G1 MA 6,12\% dan MA 8,78\%. Hal ini menunujukan ada penuruan mortalitas pada generasi 1 dibanding tetuanya. Mortalitas pada G1 dan tetua dikarenakan penyakit yang berbeda yang dicirikan oleh ciri fisik yang berbeda sehingga dari hasil analisis oleh mahasiswa pendidikan profesi koas FKH diduga koksidiosis dan sesui ciri fisik fisik yang disampaikan Iskandar et al. (2006), sedangkan pada tetuanya berdasarkan ciri fisik akibat serangan pullorum sesuai Suwito et al. (2010) gejala penyakit pullorum antara lain berak putih pada ayam atau unggasdan menyebabkan kematian.

Pada penelitian ini penyakit kematian pada generasi tetua (MA) dan generasi anak (G1 MA) disebabkan oleh penyakit yang berbeda. Dengan demikian mortalitas bukan disebabkan penyakit yang diwariskan. Penyakit yang menyerang ayam dapat dikarenakan faktor non genetik seperti dikemukakan Suprijatna et al. (2005) bahwa 
Tabel 4. Konversi persilangan interse ayam MA dan AM pada umur 1-10 minggu

\begin{tabular}{|c|c|c|c|c|}
\hline \multirow[t]{2}{*}{ Minggu } & \multicolumn{4}{|c|}{$\overline{\mathrm{x}} \pm \mathrm{sb}(\mathrm{KK} \%)$ Konversi } \\
\hline & \multicolumn{2}{|c|}{ G1 MA } & \multicolumn{2}{|c|}{ MA* } \\
\hline 1 & \multicolumn{2}{|c|}{$2,796 \pm 0,614(21,98) \mathrm{A}$} & \multicolumn{2}{|c|}{$1,851 \pm 0,204(11,03) \mathrm{B}$} \\
\hline 2 & \multicolumn{2}{|c|}{$2,201 \pm 0,634(28,79)$} & \multicolumn{2}{|c|}{$2,265 \pm 0,578(25,52)$} \\
\hline 3 & \multicolumn{2}{|c|}{$2,638 \pm 0,461(17,46)$} & \multicolumn{2}{|c|}{$2,849 \pm 0,28510,00)$} \\
\hline 4 & \multicolumn{2}{|c|}{$2,824 \pm 0,802(28,42)$} & \multicolumn{2}{|c|}{$3,103 \pm 0245(7,89)$} \\
\hline Rataan & \multicolumn{2}{|c|}{$2,615 \pm 0,288(11,00)$} & \multicolumn{2}{|c|}{$2,517 \pm 0,603(23,96)$} \\
\hline \multirow[t]{3}{*}{ Minggu } & \multicolumn{4}{|c|}{$\overline{\mathrm{x}} \pm \mathrm{sb}(\mathrm{KK} \%)$ Konversi } \\
\hline & \multicolumn{2}{|c|}{ Jantan } & \multicolumn{2}{|c|}{ Betina } \\
\hline & G1 MA & MA & G1 MA & MA \\
\hline 5 & $3,054 \pm 0,647(21,18)$ & $2,740 \pm 0,450(16,41)$ & $3,461 \pm 0,903(26,09)$ & $3,077 \pm 0,427(4,21)$ \\
\hline 6 & $3,398 \pm 0,454(13,37)$ & $2,855 \pm 0,375(3,13)$ & $3,571 \pm 0,486(13,61)$ & $3,394 \pm 0,776(22,87)$ \\
\hline 7 & $3,719 \pm 0,764(20,56)$ & $3,397 \pm 0,760(22,36)$ & $3,596 \pm 0,539(15,00)$ & $3,633 \pm 0,488(27,21)$ \\
\hline 8 & $4,203 \pm 0,888(21,13)$ & $3,419 \pm 0,533(15,60)$ & $4,030 \pm 0,760(18,85)$ & $3,814 \pm 0,461(12,08)$ \\
\hline 9 & $4,496 \pm 0,603(13,41)$ & $3,649 \pm 0,590(16,17)$ & $4,401 \pm 0,833(18,93)$ & $4,2450,331(7,79)$ \\
\hline 10 & $4,695 \pm 0,430(9,16)$ & $3,934 \pm 0,370(9,40)$ & $5,083 \pm 0,739(14,53)$ & $4,2250,487(29,36)$ \\
\hline 11 & $4,285 \pm 0,125(2,92)$ & $4,469 \pm 0,3778(8,43)$ & $4,883 \pm 0,934(19,14)$ & $5,174 \pm 0,426(0,823)$ \\
\hline 12 & $4,745 \pm 0,151(3,17)$ & $4,930 \pm 0,381(7,73)$ & $5,770 \pm 0,272(4,72)$ & $5,677 \pm 0,382(6,72)$ \\
\hline Rataan & $4,074 \pm 0,621(15,24)$ & $3,670 \pm 0880(23,98)$ & $4,361 \pm 0,826(18,95)$ & $4,116 \pm 0,959(23,30)$ \\
\hline
\end{tabular}

*) Penelitian Darwati et al. (2017), MA = Merawang arab, AM = Arab merawang, $\overline{\mathrm{x}}=$ rataan, sb = simpangan baku, KK $=\mathrm{Koefisien}$ keragaman, Angka disertai huruf besar berbeda pada baris yang sama menunjukan berbeda nyata $(\mathrm{P}<0,05)$,

mortalitas dapat disebabkan parasit, protozoa, bakteri, virus, dan cendawan. North dan Bell (1990) menyatakan penyebab kematian anak ayam dapat disebabkan kebersihan lingkungan, sanitasi peralatan dan kandang. Seperti halnya menurut Tabara (2012) penampilan unggas, penurunan pertambahan bobot badan, penurunan produktivitas, dan peningkatan kematian dan peka terhadap penyakit dapat dipengaruhi oleh panas atau dingin yang ekstrim pada lingkungan.

\section{KESIMPULAN}

Pertumbuhan G1 MA dan MA tetua tidak berbeda nyata terhadap sifat pertumbuhan umur 1-12 minggu. Komposisi genetik 50\% merawang dan 50\% arab pada G1 MA dan MA tetua menghasilkan pertumbuhan ayam yang sama.

\section{DAFTAR PUSTAKA}

Abubakar, G. T. Pambudi, \& Sunarto. 2005. Performa ayam buras dan biosekuritas di Balai Pembibitan Ternak Unggul Sapi Dwiguna dan Ayam, Di dalam: Prosiding Lokakarya Nasional Inovasi Teknologi Pengembangan Ayam Lokal, Semarang (ID), hlm: 61-85.

Amrullah, I. K. 2004. Nutrisi Ayam Broiler. Lembaga Satu Gunungnudi, Bogor.

Bell, D. D., W. D. Weaver Jr. 2002. Commercial Chicken Meat and Egg Production, Ed ke-5, Springer Science Business Media, New York.

Butcher, D. Gary, R. D. Miles. 2004, Egg Specific Gravity Designing a Monitoring Program. University of
Florida, Florida.

Curtis, S. E. 1983. Environmental Management in Animal Agriculture. The Iowa State University Pr, Iowa.

Darwati, S., R. Afnan, \& V. S. Maulana. 2017, Growh of merawang chicken with arab chicken crossing and its reciprocal at 1 to 10 weeks of age. The 7 th International Seminar on Tropical Animal Production. Universitas Gadjah Mada, Yogyakarta.

Iskandar, T., T. Didik, Subekti, \& T. Suibu. 2006. Pengaruh pemberian RBM5 terhadap koksidiosis pada ayam broiler, Seminar Nasional Teknologi Peternakan dan Veteriner. Balai Penelitian Veteriner, Bogor.

Hermawan, A. 2000. Pengaruh bobot dan indeks telur terhadap jenis kelamin anak ayam kampung pada saat menetas. Skripsi. Fakultas Peternakan, Institut Pertanian Bogor, Bogor.

Mattjik, A. A., I. M. Sumertajaya. 2013. Perancangan Percobaan dengan Aplikasi SAS dan Minitab. Jilid I. IPB Pr, Bogor.

Nataamijaya, A., A. R. Setioko, B. Brahmantyo, \& K. Diwyanto. 2003. Performans dan karakteristik tiga galur ayam lokal (pelung, arab, dan sentul). Prosiding Seminar Nasional Teknologi Peternakan dan Veteriner. Pusat Penelitian dan Pengembangan Peternakan, Bogor.

Natalia, H., D. Nista, Sunarto, \& D. S. Yuni. 2005. Pengembangan Ayam Arab. Balai Pembibitan Ternak Unggul Sembawa, Palembang.

North, M. O., D. D. Bell. 1990. Commercial Chicken Production Manual. VAN NONstrad Reinhold, New York.

Noor, R. R. 2010. Genetika Ternak. Penebar Swadaya, Jakarta. 
Rajab. 2013. Hubungan bobot telur dengan fertilitas, daya tetas, dan bobot anak ayam kampung. Agrinimal. 3(2): 55-60.

Sesmira, E. 2002. Studi fenotipik ayam kampung dan merawang umur 5-12 minggu dengan pemberian ransum yang mengandung $25 \%$ bungkil inti sawit. Skripsi. Institut Pertanian Bogor, Bogor.

Sugama, N. I., N. I. Suyasa. 2014, Karakteristik morfologis ayam buras Bali. Prosiding Seminar Nasional Sumber Daya Genetik Pertanian. Balai Pengkajian Teknologi Pertanian, Denpasar.

Suwito, D., Supriadi, \& E. Winarti. 2010. Seroprevalensi antibodi Salmonella pullorum dari peternakan sektor IV ayam buras di Gunung Kidul district, Yogyakarta. Seminar Nasional Teknologi Peternakan dan Veteriner. Balai Pengkajian Teknologi Petertanian, Yogyakarta.

Suprijatna, E., U. Atmomarsono, \& R. Kartasudjana. 2005. Ilmu Dasar Ternak Unggas. Penebar Swadaya, Jakarta.
Tabara, J. H. 2012. Respon ayam ras pedaging pada lokasi pemeliharaan daerah pantai dan pegunungan. Skripsi. Universitas Hasanuddin, Makassar.

Wineland, M. 2000. Moisture loss in hatching eggs. Abor Acress, Service Bulletin. No.14, July 15.

Yusdja, Y. R., W. K. Sajuti, I. S. Sejati, I. Anugrah, Sadikin, \& B. Winarso. 2005. Pengembangan Model Kelembagaan Agribisnis Ternak Unggas Tradisisonal (Ayam Buras, Itik dan Puyuh). Departemen Pertanianm, Jakarta.

Zainudin, D., S. Iskandar, Gunawan. 2000. Pemberian Tingkat energi dan asam amino ensensial sintetis dalam penggunaan bahan pakan lokal untuk ransum ayam buras (Generasi II). Laporan Penelitian Balai Penelitian Ternak. Balai Penelitian Ternak Ciawi, Bogor. 